Šárka Bernatíková ${ }^{1}$

Hana Tomášková

Marek Bužga ${ }^{3}$

Zdeněk Jirák ${ }^{3}$

Petr Novák ${ }^{4}$

Ján Babjak ${ }^{4}$

Tomáš Kot ${ }^{4}$

Václav Krys ${ }^{4}$

Ladislav Jánošík ${ }^{1}$

\title{
VERIFICATION OF ELECTRONIC DEVICE TECHNOLOGY FOR MEASUREMENT AND EVALUATION OF THERMAL EXPOSURE OF FIRE FIGHTERS AND MEMBERS OF RESCUE TEAMS
}

\author{
${ }^{1}$ VŠB - Technical University of Ostrava, Ostrava, Czech Republic \\ Faculty of Safety Engineering, Laboratory for Risk Research and Management \\ ${ }^{2}$ University of Ostrava, Ostrava, Czech Republic \\ Faculty of Medicine, Department of Epidemiology and Public Health \\ ${ }^{3}$ University of Ostrava, Ostrava, Czech Republic \\ Faculty of Medicine, Department of Physiology and Pathophysiology \\ ${ }^{4}$ VŠB - Technical University of Ostrava, Ostrava, Czech Republic \\ Faculty of Mechanical Engineering, Department of Robotics
}

\begin{abstract}
Background: The work of members of rescue teams could be associated with very high physical and thermal loads. If not timely interrupted, any extreme labour-thermal load may lead to a failure of the body and fatal collapse. This risk may be significantly reduced by devices that monitor the response of the body during the intervention and inform rescuers about the need to interrupt the exposure when the critical value of the reference indicator is achieved. The aim of the study was to test the correlation between the data of the newly developed device for signaling the strain of rescuers and the indicators of physiological response of the body. Material and Methods: The tests were performed on 2 physically fit fire fighters dressed in a protective rescue suit and using insulating breathing apparatus, over a wide range of heat load under a model load on a bicycle ergometer in a climatic chamber. Results: The study provided a significant correlation between the body temperature measured in the ear canal and the temperature under the suit sensed by the tested device - the Safety Ambient Monitor (SAM) $(\mathrm{R}=0.9007)$. The temperature under the suit also correlated with the temperature of the chest skin $(\mathrm{R}=0.8928)$ and heart rate $(\mathrm{R}=0.8613)$. Conclusions: A statistically significant correlation was proven between the temperature sensed by the SAM and the body temperature. The technical solution of sensing the temperature under the suit using the verified SAM technology does not affect or limit fire fighters in their work and minimizes the possibility of damage to the sensor and signaling failures. Med Pr 2018;69(1):1-11
\end{abstract}

Key words: heart rate, correlation, body temperature, fire fighter, physical strain, thermal load

Corresponding author: Šárka Bernatíková, VŠB - Technical University of Ostrava, Faculty of Safety Engineering, Laboratory for Risk Research and Management, 17. Listopadu 15/2172, 70833 Ostrava-Poruba, Czech Republic, e-mail: sarka.bernatikova@vsb.cz

Received: January 2, 2017, accepted: August 17, 2017

\section{INTRODUCTION}

In dealing with emergency situations, the work of fire fighters as well as the work of mine rescuers and members of rescue teams is spasmodically associated with high and often even extreme physical and thermal loads. If not timely interrupted, any extreme labour-thermal load may lead to a failure of the body and fatal collapse $[1,2]$.

Funding: this work was supported by the Pre-seed activity project of VŠB - Technical University of Ostrava II - Safety (registration No. CZ.1.05/3.1.00/14.0316) and the project is co-financed by the European Regional Development Fund and the state budget of the Czech Republic. Project manager: Prof. Petr Novák, M.D. Eng. 
During 12 real interventions (4 interventions when fighting house or apartment fires, 3 interventions regarding traffic accidents, trailer fire, 2 car fires, cistern fire and freeing from an elevator), the measured average heart rate (HR) was $100-120 \mathrm{~min}^{-1}$ but fitfully it reached even $180 \mathrm{~min}^{-1}$. The corresponding average values of energy expenditure (EV) ranged between $15-25 \mathrm{~kJ} \times \mathrm{min}^{-1}$; on a short-term basis, however, they reached net values of $50-60 \mathrm{~kJ} \times \mathrm{min}^{-1}[3]$.

In the model situations, when carrying a wounded person under difficult circumstances and when ascending quickly up the stairs with baskets containing 1 or 2 hoses to the 6th floor (measured using an integral method), the net EV was $48-130 \mathrm{~kJ} \times \mathrm{min}^{-1}$ (888-2167 W) whereas the HR values at the ascent end were around $180 \mathrm{~min}^{-1}$ [3]. Similarly are high values found by a number of authors in testing fire fighters as well as mine rescuers [4].

For the model conditions in the mine, the measured values of energy expenditure ranged between $184 \mathrm{~W}$ and $966 \mathrm{~W}$, while the average $\mathrm{HR}$ values were around $153 \pm 17 \mathrm{~min}^{-1}$; however, short-term HR values were $180-200 \mathrm{~min}^{-1}$. The core body temperature reached the average values of $38.1-38.3^{\circ} \mathrm{C}$, individually even up to $38.9^{\circ} \mathrm{C}$ [5-7]. Working conditions are especially challenging if the work must be done with a breathing apparatus $[5,8,9]$. Health risk may be significantly reduced by devices that monitor the response of the body during the intervention and inform rescuers about the need to interrupt the exposure when the critical value of the reference indicator is achieved.

In work-medical practice, evaluation of the labour-thermal load of workers in hot workplaces takes grounds in changes of physiological parameters, primarily the body core temperature, liquid loss by perspiration and respiration, heart rate, and skin temperature. The evaluation also may use computation programs to predict perspiration production and body core temperature stemming from accurately defined indicators on metabolic production of the organism, heat-humidity conditions of the environment, and thermal resistance of clothing $[10,11]$.

Recently, Yokota et al. [12] have published a model for evaluation of the labour-thermal load, which enables to predict body core temperature, skin temperature, perspiration production and heat stress index (physiological strain index (PSI) [13]) based on input data including microclimatic conditions of the environment, HR, metabolic production, height, weight, and clothes characteristics. These methods have only limited use in monitoring load of fire fighters and rescuers in terrain conditions due to unpredictable and quickly changing heat-humidity conditions at the place of the intervention. Monitoring of the labour-thermal load of fire fighters and rescuers in terrain conditions requires using methods that put minimal load on the worker and are safe from the point of view of possible faults and failures of the early warning system.

The best indicator of organism overheating is the body core temperature $\left(\mathrm{t}_{c}\right)$ which reacts to metabolic and climatic load. Its direct measurement in terrain conditions is not possible. The only mini-invasive system for remote monitoring of $t_{c}$ is a thermometer pill, although its routine use is limited due to high costs and results may be influenced by water and food intake [14]. This is the reason to search for methods that would be accurate enough (better than $\pm 0.5^{\circ} \mathrm{C}$ ) to determine the body core temperature from physiological indicators well-measured on the body surface under non-rest conditions. In the past methods were published to have been based on prediction of the body core temperature from temperature measured at selected places on the skin, thermal flow on the skin and heart rate [14-16] or only from the heart rate [17].

The methods were verified in the laboratory and terrain conditions in a wide range of thermal-humid conditions, metabolic demands, and various clothes. The reliability of the calculated values compared with the body core temperature measured by some of the invasive methods (rectal temperature, esophageal, intestinal) was better than the required $\pm 0.5^{\circ} \mathrm{C}$. Although the mentioned methods are maximally gentle from the monitored person's point of view, they required scanning the monitored parameters directly from the surface of the monitored person, which might be the cause of faults and failures of the early warning system.

The aim of the work was to validate the correlation between data measured using the technology of the Safety Ambient Monitor (SAM) and indicators of physiological responses of the body under experimental conditions of a climatic chamber.

\section{MATERIAL AND METHODS}

The Safety Ambient Monitor device (Photo 1) was developed at the VŠB - Technical University of Ostrava for monitoring and evaluation of those working conditions in order to minimize hazard by an early warning. 


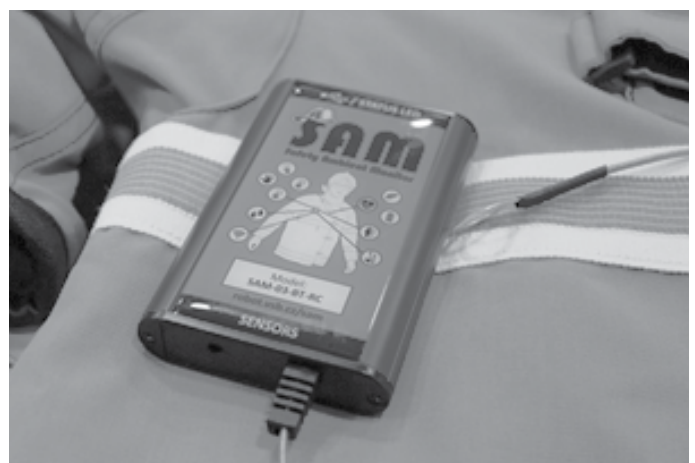

Photo 1. Safety Ambient Monitor (SAM) - the tested device measuring thermal exposure of fire fighters and members of rescue teams, and signaling the strain of rescuers and the indicators of physiological response of the body

The device records and evaluates the air temperature and humidity under the suit and outdoor temperature. Based on defined limits, it signals any excess of these limits and alerts wearers to impending critical conditions of body overheating. The device also registers and analyzes movements of the monitored person and alerts to loss of consciousness or to fall from a height of that person. The unit weighs about $130 \mathrm{~g}$, has a size of a mobile phone and its battery lasts $48 \mathrm{~h}$. Charging is done via a micro-USB connector and the unit parameters are set from a PC.

For testing purposes, we selected 2 professional fire fighters (FF) aged 32 and 42 years old, well adapted for the profession of a fire fighter (seniority as a fire fighter, respectively: 10 years and 13 years) and physically fit (maximal oxygen consumption per minute $\left(\mathrm{VO}_{2 \max }\right)=$ $43.6 \mathrm{ml} / \mathrm{min} / \mathrm{kg}$ and $42.7 \mathrm{ml} / \mathrm{min} / \mathrm{kg}$ ), who, prior to testing, had successfully passed the stress test in a functional laboratory of the Department of Physiology and Pathophysiology, Faculty of Medicine, University of Ostrava, Ostrava, the Czech Republic.

First of all, those experimental persons (fire fighter 1 - FF1, fire fighter 2 - FF2) completed a continuous load test on a bicycle ergometer (Ergo 900, Ergo-Line), in the case of which the load, after an initial warm-up, rose from the start value of $75 \mathrm{~W}$ by $25 \mathrm{~W}$ every minute up to maximum. Fans' parameters were found and the gas analysis was done using the instrument $\mathrm{Oxy}$ conPro (Jaeger - CareFusion, Germany). The achieved values of the maximum oxygen consumption per minute, heart rate (HR) and $\mathrm{VO}_{2}$ at the level of anaerobic threshold (AT) are listed in the Table 1.

After a complete 2-hour recovery in optimal microclimate conditions, they underwent a submaximal exercise test according to the design by Hollmann [18], in which the load was increased for the start value of $30 \mathrm{~W}$ every $3 \mathrm{~min}$ by $40 \mathrm{~W}$. The FFs underwent this test in the laboratory microclimatic conditions in the rescue suit with the same equipment as during the subsequent testing in the climatic chamber.

The FFs were dressed in a standard rescue suit Tiger Plus. Under the suit, they had short underpants, a T-shirt with short sleeves and socks. Both of them had rescue leather shoes afoot and standard helmets for fire fighters on their heads. On their backs, they were carrying a breathing apparatus weighing $14.1 \mathrm{~kg}$ (Photo 2). During the test the FFs did not use a breathing apparatus, but Oxycon Pro analyzer. Oxycon Pro has automatic calibration and its accuracy of measurement is $3 \%$ or $0.05 \mathrm{l} / \mathrm{min}$.

The results were used for calculating individual equations for the relationship between the magnitude of the load and strain physiological indicators.

The technology for signaling the load of rescuers was verified in a climatic chamber of the Department of Work Physiology at the Health Institute in Ostrava. The climatic chamber has an inner space of $2 \times 3 \times 2 \mathrm{~m}$. Conditioned air is conveyed to the chamber from an engine room through a duct hole sized $1 \times 1 \mathrm{~m}$ and located in the wall along the chamber longitudinal

Table 1. Continuous load ${ }^{\star}$ test of professional fire fighters on a bicycle ergometer in the climatic chamber in suit under normal heat-humidity conditions

\begin{tabular}{|c|c|c|c|c|c|c|c|c|}
\hline \multirow{3}{*}{ Fire fighter } & \multirow{3}{*}{$\begin{array}{c}\text { Age } \\
\text { [years] }\end{array}$} & \multirow{3}{*}{$\begin{array}{c}\text { Body weight } \\
{[\mathrm{kg}]}\end{array}$} & \multicolumn{6}{|c|}{ Parameters } \\
\hline & & & \multirow{2}{*}{$\begin{array}{l}\mathrm{VO}_{2 \max } \\
{[1 / \mathrm{min}]}\end{array}$} & \multirow{2}{*}{$\begin{array}{l}\mathrm{VO}_{2 \max } / \mathrm{kg} \\
{[\mathrm{ml} / \mathrm{min}]}\end{array}$} & \multirow{2}{*}{$\begin{array}{l}\mathrm{HR}_{\text {max }} \\
{[\mathrm{bpm}]}\end{array}$} & \multirow{2}{*}{$\begin{array}{l}\mathrm{W}_{\max } / \mathrm{kg} \\
{[\mathrm{W} / \mathrm{kg}]}\end{array}$} & \multicolumn{2}{|c|}{$\mathrm{AT}$} \\
\hline & & & & & & & $\begin{array}{c}\mathrm{HR} \\
{[\mathrm{bpm}]}\end{array}$ & $\begin{array}{c}\mathrm{VO}_{2} \\
{[1 / \mathrm{min}]}\end{array}$ \\
\hline $\mathrm{FF} 1(\mathrm{~N}=1)$ & 32 & 75.8 & 3.30 & 43.6 & 184 & 4.0 & 130 & 1.6 \\
\hline $\mathrm{FF} 2(\mathrm{~N}=1)$ & 42 & 86.0 & 3.67 & 42.7 & 160 & 3.8 & 134 & 2.4 \\
\hline
\end{tabular}

* Load (after an initial warm-up) rises from the start value of $75 \mathrm{~W}$ by $25 \mathrm{~W}$ every minute up to maximum value.

FF1 - a person with 10-year-exposure as a fire fighter, FF2 - a person with 13-year-exposure as a fire fighter.

$\mathrm{VO}_{2 \max }$ - maximum oxygen consumption per minute, $\mathrm{VO}_{2 \max } / \mathrm{kg}$ - oxygen consumption per $\mathrm{kg}$ of weight, $\mathrm{HR}_{\max }-\mathrm{maximum}$ heart rate, $\mathrm{W}_{\max } / \mathrm{kg}-\mathrm{maximum}_{\mathrm{m}} \mathrm{mork}$ rate achieved during an incremental cycle ergometer test per kg, AT - the values of the heart rate with the corresponding oxygen consumption at anaerobic threshold. 


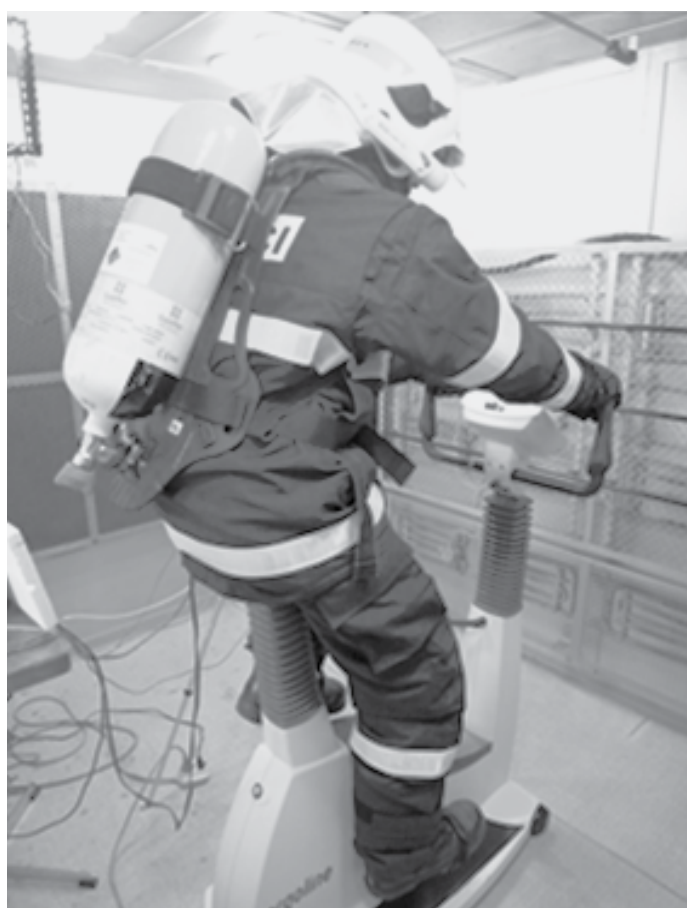

Photo 2. Fire fighter in a standard rescue suit with breathing apparatus on a bicycle ergometer in the model work (load value: $100 \mathrm{~W}$ ) inside the climatic chamber

axis and removed in the wall on the opposite side (Figure 1).

The back wall of the chamber is created by a radiating panel. The source of radiation is 12 heating units (each of $250 \mathrm{~W}$ ) connected serially and placed in 3 superposed rows. There are 3 metal rods and a metal net to protect the heating units from a direct contact. The

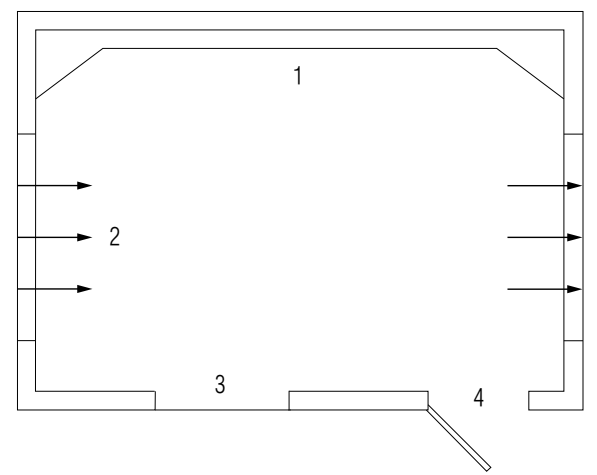

1 - vertical radiant panel, 2 - air flow direction, 3 - control room window, 4 - entrance to the chamber.

Inner space: $2 \times 3 \times 2 \mathrm{~m}$.

Arrows - direction of conditioned air, which is conveyed to the chamber from an engine room through a duct hole located in the wall and sized $1 \times 1 \mathrm{~m}$, along the chamber longitudinal axis, and removed in the wall on the opposite side.

Fig. 1. Climatic chamber used for the professional fire fighter load test chamber allows for experimenters to adjust the air temperature in the range $20-60^{\circ} \mathrm{C}$, airflow speed in the range of $0.2-2.0 \mathrm{~m} \times \mathrm{s}^{-1}$, relative humidity in the range of $30-90 \%$. Intensity of heat radiation from the back wall of the chamber $\left(\mathrm{I}_{\mathrm{A}}\right)$ can be gradually increased up to $700 \mathrm{~W} \times \mathrm{m}^{-2}$.

The load on the bicycle ergometer in the climatic chamber was set uniformly at $100 \mathrm{~W}$ for all phases. The calculated values of the oxygen consumption per minute, heart rate, and energy expenditure ( $\mathrm{kJ}, \mathrm{W})$, which the FFs reach after the $100 \mathrm{~W}$ load in a fire fighter's suit under normal heat-humidity conditions, are stated in the Table 2.

Ambient conditions were continuously measured at a height of $110 \mathrm{~cm}$ above the floor, at the level of the chest of experimental persons. The measured physical parameters, dry air temperature $\left(\mathrm{t}_{\mathrm{a}}\right)\left({ }^{\circ} \mathrm{C}\right)$, air relative humidity $(\mathrm{RH})(\%)$, air velocity $\left(\mathrm{v}_{\mathrm{a}}\right)\left(\mathrm{m} \times \mathrm{s}^{-1}\right)$, radiation temperature in the direction from the chamber front wall $\left(\mathrm{t}_{\mathrm{rA}}\right)\left({ }^{\circ} \mathrm{C}\right)$ and from the opposite wall $\left(\mathrm{t}_{\mathrm{rB}}\right)\left({ }^{\circ} \mathrm{C}\right)$, and the intensity of radiation from the chamber front wall $\left(\mathrm{I}_{\mathrm{rA}}\right)\left(\mathrm{W} \times \mathrm{m}^{-2}\right)$ and from the opposite wall $\left(\mathrm{I}_{\mathrm{rB}}\right)\left(\mathrm{W} \times \mathrm{m}^{-2}\right)$, were measured using the instrument - the Indoor Climate Analyzer, type 1213, made by the company Bruel and Kjaer.

The resulting temperature $\left(\mathrm{t}_{\mathrm{g}}\right)\left({ }^{\circ} \mathrm{C}\right)$ was measured with a spherical thermometer made by Ahlborn company, having a ball diameter of $150 \mathrm{~mm}$. Monitored values were recorded at 3-minute intervals. For each phase, the measured values were used for calculating mean values and standard deviations (SD). Detailed heat-humidity conditions measured during each phase are given in the Table 3.

In all stages, the FFs were forehead-oriented to the radiating panel. To be able to communicate, the FFs were not connected to a breathing apparatus and they breathed atmospheric air from the chamber. Within 2 testing days, the FFs passed 5 phases

Table 2. Professional fire fighter parameters after the load of $100 \mathrm{~W}$ on the bicycle ergometer in the climatic chamber in suit under normal heat-humidity conditions

\begin{tabular}{|c|c|c|c|c|c|}
\hline \multirow[b]{2}{*}{ Fire fighter } & \multirow{2}{*}{$\begin{array}{c}\mathrm{VO}_{2} \\
{[1 / \mathrm{min}]}\end{array}$} & \multirow{2}{*}{$\begin{array}{c}\mathrm{HR} \\
{[\mathrm{bpm}]}\end{array}$} & \multicolumn{3}{|c|}{ Energy expenditure } \\
\hline & & & $\begin{array}{l}\mathrm{kJ} / \mathrm{min} \\
\text { (gross) }\end{array}$ & $\begin{array}{c}\mathrm{kJ} / \mathrm{min} \\
\text { (net) }\end{array}$ & $\begin{array}{c}\mathrm{W} \\
\text { (net) }\end{array}$ \\
\hline $\mathrm{FF} 1(\mathrm{~N}=1)$ & 1.48 & 140 & 30.28 & 25.0 & 416.8 \\
\hline $\mathrm{FF} 2(\mathrm{~N}=1)$ & 1.67 & 132 & 33.51 & 28.2 & 470.6 \\
\hline
\end{tabular}

FF1 - a person with 10-year-exposure as a fire fighter,

FF2 - a person with 13-year-exposure as a fire fighter.

$\mathrm{VO}_{2}$ - oxygen consumption per minute, $\mathrm{HR}$ - heart rate. 


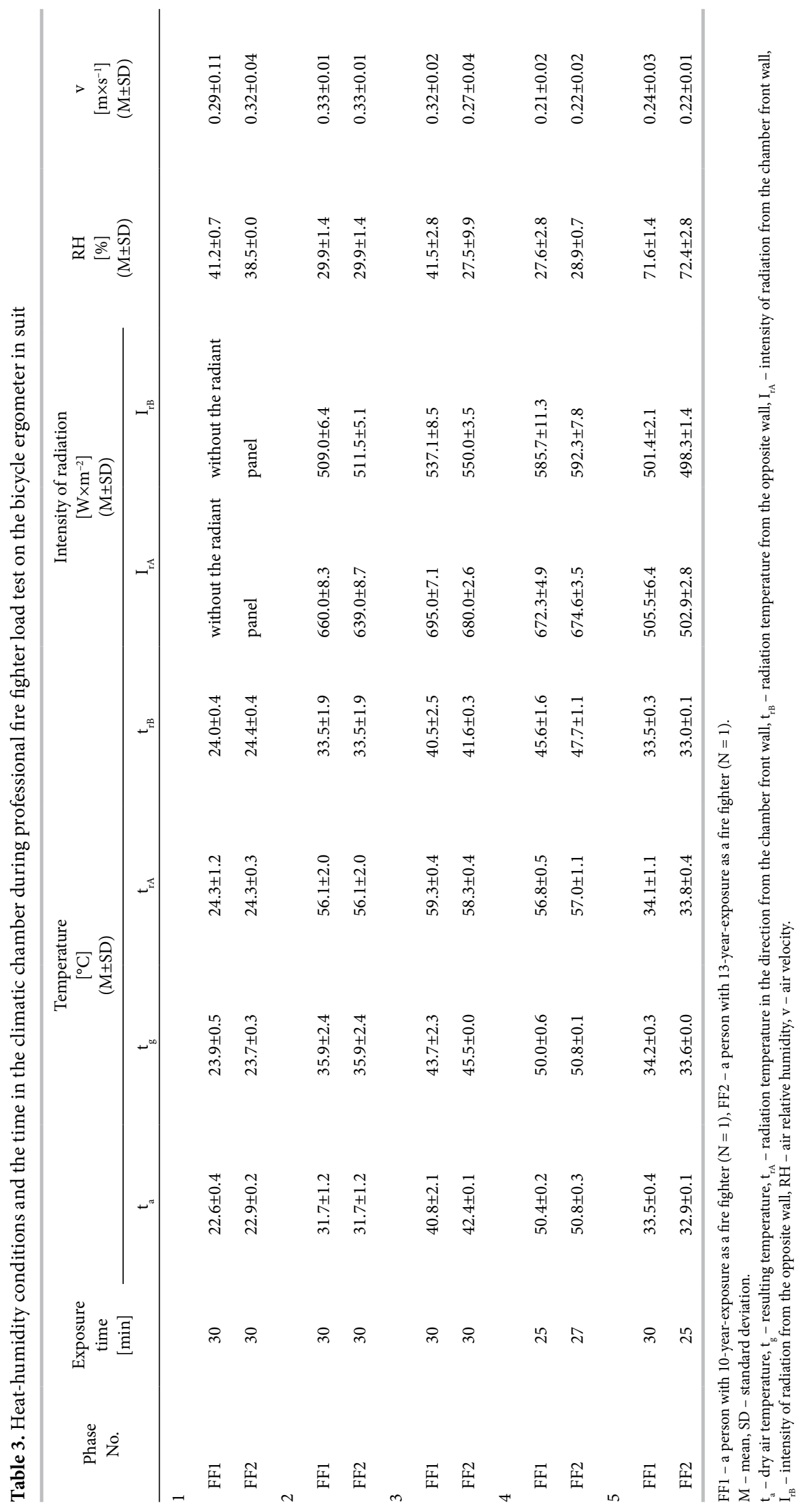


(P1-P5) with different air temperature, radiation intensity and relative humidity (RH). During phases P1-P4, the thermal load was increased from a very modest load in $\mathrm{P} 1\left(\mathrm{t}_{\mathrm{a}}=22^{\circ} \mathrm{C}, \mathrm{t}_{\mathrm{rA}}=24^{\circ} \mathrm{C}, \mathrm{RH}=30-40 \%\right)$ up to $\mathrm{P} 4$ $\left(\mathrm{t}_{\mathrm{a}}=50^{\circ} \mathrm{C}, \mathrm{t}_{\mathrm{rA}}=57^{\circ} \mathrm{C}, \mathrm{RH}=30 \%\right)$. In $\mathrm{P} 5$, the relative humidity was very high $(\mathrm{RH}=70 \%)$ at relatively low air temperature $\left(\mathrm{t}_{\mathrm{a}}=33^{\circ} \mathrm{C}\right)$ and temperature from the chamber front wall $\mathrm{t}_{\mathrm{rA}}=34^{\circ} \mathrm{C}$. Intensity of radiation was adjusted to achieve the desired air temperature $\left(t_{\mathrm{a}}\right)$ in individual phases P1-P5.

The period of exposure in various phases was set to 30 min or until reaching critical HR or body temperature values. The exceeded limit value was the reason to interrupt the test and to set it to HR 200-age and the body core temperature $-38.5^{\circ} \mathrm{C}$. On the first testing day, the FFs underwent phase E1 and E2, on the second day - stage E3 to E5, and between individual phases, there was a 2-hour break which the FFs spent in light clothes in optimal climatic conditions in a rest room.

Monitored physiological parameters, heart rate (HR) $(\mathrm{bpm})$ and the skin temperature at the inferior sternum $\left(\mathrm{t}_{\text {sk,chest }}\right)\left({ }^{\circ} \mathrm{C}\right)$ were measured using the multivariable monitoring device - MLE 120X BioHarness. The HR was captured through electrode sensors housed within the chest strap with the TEAM System station for BioHarness device. Skin temperature data was collected through an infrared sensitive sensor behind a clear window on the apex of the monitoring device; values were displayed on a monitor and continuously recorded at 30-second intervals in the memory of the computer. Precision of measurement for HR data is $< \pm 1$ beat $/ \mathrm{min}$; for methods involving temperature measurement, a threshold of accuracy stands at $0.1^{\circ} \mathrm{C}[19]$.

The body core temperature was measured continuously in the left ear canal $\left(\mathrm{t}_{\mathrm{ac}}\right)\left({ }^{\circ} \mathrm{C}\right)$ using the thermocouple type $\mathrm{T}$ sensor with accuracy of $\pm 0.2 \mathrm{~K}$. Having otoscopically checked the cleanliness of the ear canal, the temperature sensor was introduced deep into the ear canal and thermally shielded by a 5-centimeter foam insulation and helmet plastic skeleton.

The measured values were continuously displayed on the monitor and saved in the computer memory. The device for signaling the load, the SAM, was placed in the inner pocket of the rescue suit on the right chest side. Through the hole in the pocket, the sensors of the SAM for the continuous measurement of the microclimate temperature $\left(t_{\text {suit }}\right)$ and relative humidity $\left(\mathrm{RH}_{\text {suit }}\right)$ measured microclimate in the space between the outer and inner layers of the suit. The suit surface temperature $\left(\mathrm{t}_{\text {surface }}\right)$ was measured contactlessly shortly after entering the chamber and just before leaving the chamber.

Loss of water due to sweating and breathing (SR) (ml) was measured by weighing FFs before entering and immediately after leaving the climate chamber. During their stay in the climatic chamber, EPs did not eat and drink. At the end of each phase, EPs evaluated their subjective feeling of physical strain and fatigue using a 5-point scales created by authors (Table 4 and 5).

Table 4. Scale of subjective evaluation of the amount of labour-thermal load

\begin{tabular}{|c|c|}
\hline $\begin{array}{l}\text { Load } \\
\text { intensity }\end{array}$ & Labour-thermal load \\
\hline 1 & very light load with no uncomfortable subjective feelings \\
\hline 2 & $\begin{array}{l}\text { light load with minor uncomfortable subjective feelings, } \\
\text { which can be tolerated for a very long time }\end{array}$ \\
\hline 3 & $\begin{array}{l}\text { medium load with mid-intensive uncomfortable feelings, } \\
\text { which can be tolerated for quite a long time }\end{array}$ \\
\hline 4 & $\begin{array}{l}\text { intensive load with uncomfortable feelings, which can be } \\
\text { hardly tolerated even for a very short time }\end{array}$ \\
\hline 5 & $\begin{array}{l}\text { very intensive load with very uncomfortable subjective } \\
\text { feelings leading to the feeling of exhaustion after a very short } \\
\text { time with the need to interrupt the work }\end{array}$ \\
\hline
\end{tabular}

Table 5. Scale of subjective evaluation of the tiredness level after experiments in the climatic chamber

\begin{tabular}{ll}
\hline $\begin{array}{c}\text { Tiredness } \\
\text { level }\end{array}$ & \multicolumn{1}{c}{ Feelings after the labour-thermal load } \\
\hline 1 & pleasantly tired \\
2 & slightly tired \\
3 & quite tired \\
4 & very tired \\
5 & exhausted \\
\hline
\end{tabular}

For purposes of statistical evaluation, authors used correlation and regression analyses with the chosen significance level of 5\%. Processing was performed using Stata software, version 13.

\section{RESULTS}

In various phases, the average production of sweat per hour did not vary too much and ranged around $1.38 \pm 0.13 \mathrm{l} / \mathrm{h}, 3$ were no statistically significant differences among the phases. The temperature on the suit 
surface at the end of the load reached $28.7^{\circ} \mathrm{C}$ in $\mathrm{P} 1$ up to $49.8^{\circ} \mathrm{C}$ in $\mathrm{P} 4$ on the back (in the direction of radiation) and $26.4^{\circ} \mathrm{C}$ in $\mathrm{P} 1$ up to $44.7^{\circ} \mathrm{C}$ in $\mathrm{P} 4$ on the chest. At the end of $\mathrm{P} 3$ and $\mathrm{P} 4$, the heart rate exceeded the limit values of $\mathrm{SF}_{\max }$, approaching to the maximum values; the body core temperature measured in the ear canal also exceeded the limit value of $38.5^{\circ} \mathrm{C}$ during the stated phases. During P5, all the indicators of FFs reached lower values than in $\mathrm{P} 4$.

Experimental persons (FFs) assessed the load magnitude with grade 1-3 (very slight to medium load causing moderately intensive unpleasant subjective feelings which can be tolerated for quite a long time) within P1 to $\mathrm{P} 3$, and with grade 4 (intensive load associated with unpleasant sensations which can be tolerated only with great effort for a short time) within P4 and P5. They assessed the feeling of fatigue with grade 1 (pleasantly tired) within P1 and P2, and with grade 3 (rather tired) within P3 to P5.

Minimum and maximum values of basic physiological indicators, i.e., the body temperature measured in the ear canal $\left(\mathrm{t}_{\mathrm{ac}}\right)$, heart rate (HR) and the skin temperature on the chest $\left(\mathrm{t}_{\text {sk,chest }}\right)$, and the values measured by the SAM device, i.e., the air temperature measured under the suit $\left(\mathrm{t}_{\text {suit }}\right)$ and air relative humidity measured under the suit $\left(\mathrm{RH}_{\text {suit }}\right)$, found during individual experiments and their differences are shown in the Table 6.

The relationship between basic physiological indicators $\left(\mathrm{HR}, \mathrm{t}_{\mathrm{ac}}, \mathrm{t}_{\mathrm{sk}, \text { chest }}\right)$ on the one hand and the values measured by the verified SAM technology $\left(\mathrm{t}_{\text {suit }}, \mathrm{RH}_{\text {suit }}\right)$

Table 6. Physiological indicators for professional fire fighters (FF1, FF2) during individual experiments within 5 phases in the climatic chamber

\begin{tabular}{|c|c|c|c|c|c|c|c|c|c|c|}
\hline \multirow{2}{*}{$\begin{array}{c}\text { Experiment } \\
\text { No. }\end{array}$} & \multicolumn{2}{|c|}{$\begin{array}{c}\mathrm{t}_{\mathrm{ac}} \\
{\left[{ }^{\circ} \mathrm{C}\right]}\end{array}$} & \multicolumn{2}{|c|}{$\begin{array}{c}\mathrm{HR} \\
{[\mathrm{bpm}]}\end{array}$} & \multicolumn{2}{|c|}{$\begin{array}{l}\mathrm{t}_{\text {sk,chest }} \\
{\left[{ }^{\circ} \mathrm{C}\right]}\end{array}$} & \multicolumn{2}{|c|}{$\begin{array}{c}\mathrm{t}_{\text {suit }} \\
{\left[{ }^{\circ} \mathrm{C}\right]}\end{array}$} & \multicolumn{2}{|c|}{$\begin{array}{l}\mathrm{RH}_{\text {suit }} \\
{\left[{ }^{\circ} \mathrm{C}\right]}\end{array}$} \\
\hline & FF1 & FF2 & FF1 & FF2 & FF1 & FF2 & FF1 & FF2 & FF1 & FF2 \\
\hline \multicolumn{11}{|l|}{1} \\
\hline $\min$. & 35.8 & 35.5 & 94 & 61 & 33.4 & 34.6 & 28.0 & 27.4 & 62.9 & 53.4 \\
\hline $\max$ & 37.1 & 37.0 & 163 & 137 & 35.4 & 36.3 & 33.6 & 34.0 & 81.8 & 89.8 \\
\hline increase & 1.3 & 1.5 & 69 & 76 & 2.0 & 1.7 & 5.6 & 6.6 & 18.9 & 36.4 \\
\hline \multicolumn{11}{|l|}{2} \\
\hline $\min$. & failure & 34.7 & 65 & 61 & 32.9 & 35.0 & 28.4 & 28.6 & 70.9 & 59.0 \\
\hline $\max$ & & 37.6 & 157 & 158 & 37.0 & 37.1 & 35.4 & 36.1 & 91.7 & 88.4 \\
\hline increase & & 2.9 & 92 & 97 & 4.2 & 2.1 & 7.0 & 7.5 & 20.8 & 29.4 \\
\hline \multicolumn{11}{|l|}{3} \\
\hline $\min$. & 35.6 & 33.1 & 110 & 61 & 34.4 & 35.1 & 29.5 & 29.0 & 66.9 & 58.2 \\
\hline $\max$ & 38.5 & 37.7 & 196 & 170 & 38.0 & 37.7 & 38.1 & 38.2 & 89.7 & 88.6 \\
\hline increase & 2.9 & 2.3 & 85 & 109 & 3.5 & 2.5 & 8.6 & 9.2 & 22.8 & 30.4 \\
\hline \multicolumn{11}{|l|}{4} \\
\hline $\min$. & 34.6 & 35.4 & 78 & 61 & 34.5 & 35.2 & 28.5 & 31.0 & 58.2 & 53.6 \\
\hline $\max$ & 38.6 & 38.8 & 173 & 178 & 38.2 & 38.6 & 39.3 & 39.7 & 85.1 & 83.2 \\
\hline increase & 4.1 & 3.5 & 94 & 117 & 3.6 & 2.9 & 10.8 & 8.7 & 26.9 & 29.6 \\
\hline \multicolumn{11}{|l|}{5} \\
\hline $\min$. & 34.4 & 35.4 & 84 & 61 & 34.9 & 35.6 & 29.7 & 31.7 & 58.8 & 55.2 \\
\hline $\max$ & 37.8 & 37.9 & 173 & 175 & 37.2 & 37.2 & 37.9 & 37.3 & 83.1 & 82.2 \\
\hline increase & 3.3 & 2.6 & 89 & 114 & 2.3 & 1.6 & 8.2 & 5.6 & 24.3 & 27.0 \\
\hline
\end{tabular}

FF1 - a person with 10-year-exposure as a fire fighter $(\mathrm{N}=1), \mathrm{FF} 2$ - a person with 13-year-exposure as a fire fighter $(\mathrm{N}=1)$.

min. - minimal value, max - maximal value.

$\mathrm{t}_{\mathrm{ac}}$ - body temperature measured in the ear canal, HR - heart rate, $\mathrm{t}_{\mathrm{sk}, \text { chest }}$ - skin temperature measured on the left side of the chest using glued thermistor sensors,

$\mathrm{t}_{\text {suit }}$ - air temperature measured between the outer and inner layer of the suit by the verified technology for signaling the load (safety ambient monitor - SAM),

$\mathrm{RH}_{\text {suit }}$ - air relative humidity measured between the outer and inner layer of the suit by the verified technology for signaling the load (SAM).

Other abbreviations as in Table 3 . 
Table 7. Relationships between the air temperature $\left(\mathrm{t}_{\text {suit }}\right)$ and the air relative humidity $\left(\mathrm{RH}_{\text {suit }}\right)$ measured under the suit of professional fire fighters by the verified technology for signaling the load (safety ambient monitor - SAM) and the load physiological indicators: body temperature $\left(t_{a c}\right)$, heart rate $(H R)$ and the temperature of the chest skin $\left(\mathrm{t}_{\mathrm{sk}, \mathrm{chest}}\right)$

\begin{tabular}{lll}
\hline \multicolumn{1}{c}{ Relationship } & \multicolumn{1}{c}{ Equation } & $\begin{array}{c}\text { Correlation } \\
\text { coefficient }\end{array}$ \\
\hline $\mathrm{t}_{\text {ac }}: \mathrm{t}_{\text {suit }}$ & $\mathrm{t}_{\mathrm{ac}}=27.32+0.28 \times \mathrm{t}_{\text {suit }}\left[{ }^{\circ} \mathrm{C}\right]$ & 0.9007 \\
$\mathrm{t}_{\mathrm{ac}}: \mathrm{RH}_{\text {suit }}$ & $\mathrm{t}_{\mathrm{ac}}=0.06 \times \mathrm{RH}_{\text {suit }}+31.98\left[{ }^{\circ} \mathrm{C}\right]$ & 0.6651 \\
$\mathrm{HR}: \mathrm{t}_{\text {suit }}$ & $\mathrm{HR}=-77.65+6.6 \times \mathrm{t}_{\text {suit }}[\mathrm{bpm}]$ & 0.8613 \\
$\mathrm{HR}: \mathrm{RH}_{\text {suit }}$ & $\mathrm{HR}=28.22+1.47 \times \mathrm{RH}_{\text {suit }}[\mathrm{bpm}]$ & 0.6292 \\
$\mathrm{t}_{\text {sk,chest }}: \mathrm{t}_{\text {suit }}$ & $\mathrm{t}_{\text {sk,chest }}=18.31+0.5 \times \mathrm{t}_{\text {suit }}\left[{ }^{\circ} \mathrm{C}\right]$ & 0.8928 \\
$\mathrm{t}_{\text {sk,chest }}: \mathrm{RH}_{\text {suit }}$ & $\mathrm{t}_{\text {sk,chest }}=25.00+0.13 \times \mathrm{RH}_{\text {suit }}\left[{ }^{\circ} \mathrm{C}\right]$ & 0.7512 \\
\hline
\end{tabular}

${ }^{*} \mathrm{p}<0.05$.

Abbreviations as in Table 6.

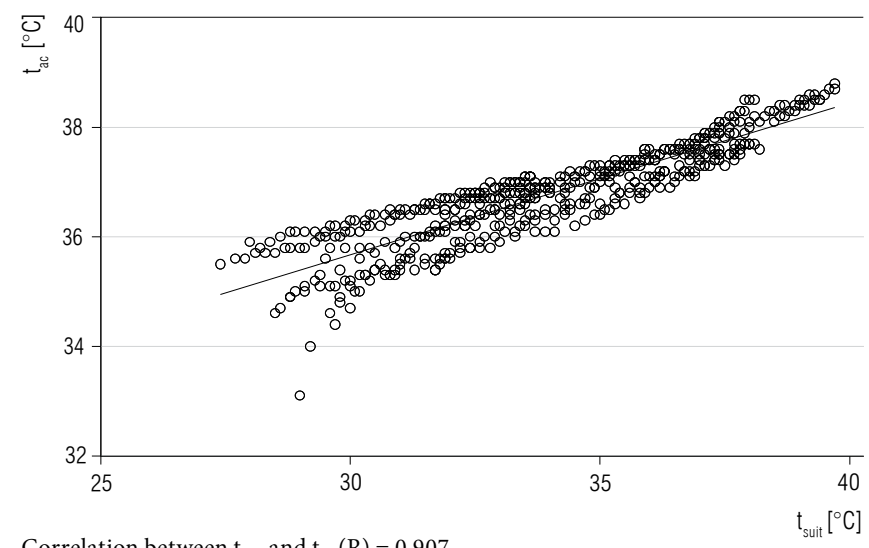

Correlation between $\mathrm{t}_{\text {suit }}$ and $\mathrm{t}_{\mathrm{ac}}(\mathrm{R})=0.907$.

Fig. 2. Relationship between the professional fire fighters' body temperature measured in the ear canal $\left(\mathrm{t}_{\mathrm{ac}}\right)$ and the air temperature measured between the upper and the inner layer of the suit by the verified technology for signaling the load $\left(\mathrm{t}_{\text {suit }}\right)$

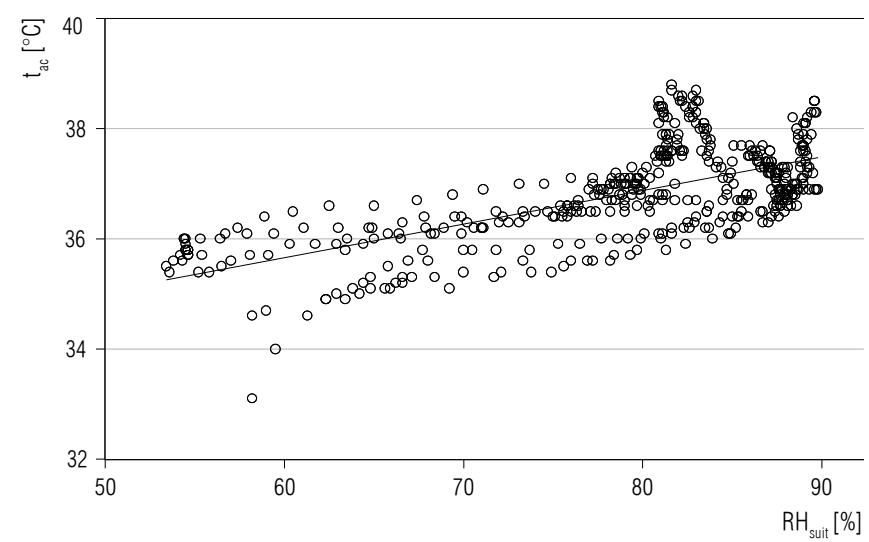

Correlation between $\mathrm{RH}_{\text {suit }}$ and $\mathrm{t}_{\mathrm{ac}}(\mathrm{R})=0.6651$.

Fig. 3. Relationship between the professional fire fighters' body temperature measured in the ear canal $\left(\mathrm{t}_{\mathrm{ac}}\right)$ and the air relative humidity measured between the upper and the inner layer of the suit by the verified technology for signaling the load $\left(\mathrm{RH}_{\text {suit }}\right)$

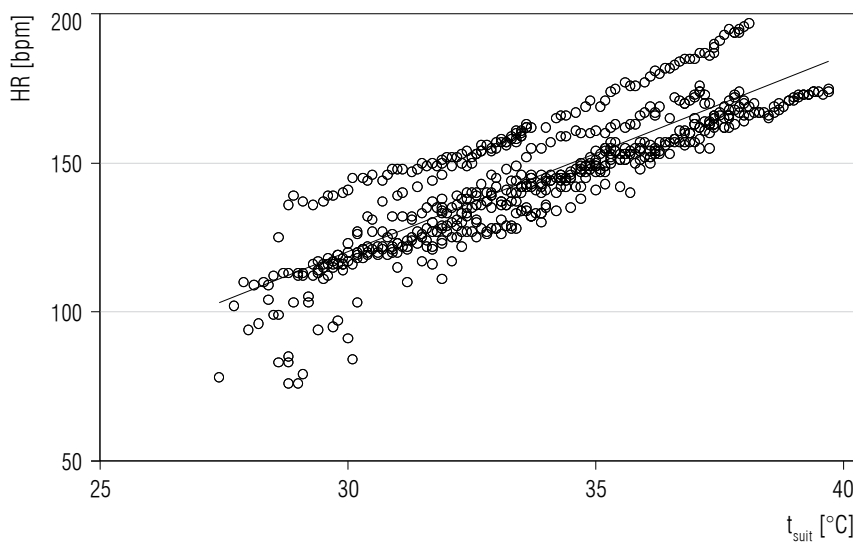

Correlation between $\mathrm{t}_{\text {suit }}$ and $\mathrm{HR}(\mathrm{R})=0.8613$.

Fig. 4. Relationship between the professional fire fighters' heart rate $(\mathrm{HR})$ and air temperature measured between the outer and inner layer of the suit by the testing device $\left(\mathrm{t}_{\text {suit }}\right)$

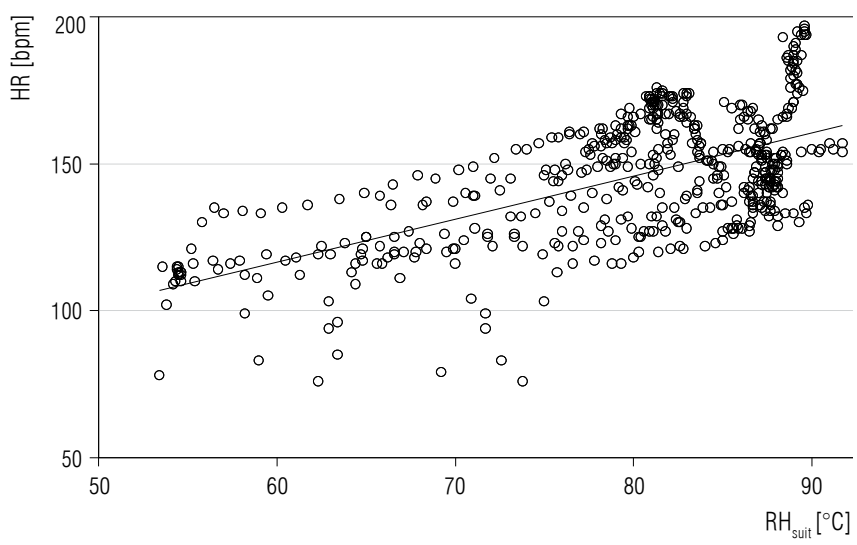

Correlation between $\mathrm{RH}_{\text {suit }}$ and $\mathrm{HR}(\mathrm{R})=0.6292$.

Fig. 5. Relationship between the professional fire fighters' heart rate (HR) and relative air humidity measured between the outer and inner layer of the suit by the testing device $\left(\mathrm{RH}_{\text {suit }}\right)$

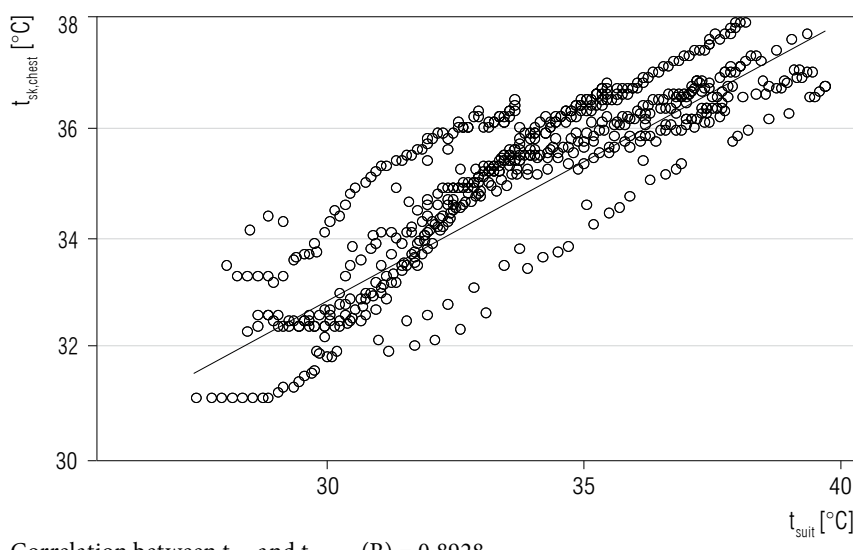

Correlation between $\mathrm{t}_{\text {suit }}$ and $\mathrm{t}_{\mathrm{sk}, \text { chest }}(\mathrm{R})=0.8928$.

Fig. 6. Relationship between the professional fire fighters' skin temperature measured on the chest $\left(\mathrm{t}_{\text {sk,chest }}\right)$ and air temperature measured between the outer and inner layer of the suit by the testing device $\left(\mathrm{t}_{\text {suit }}\right)$ 


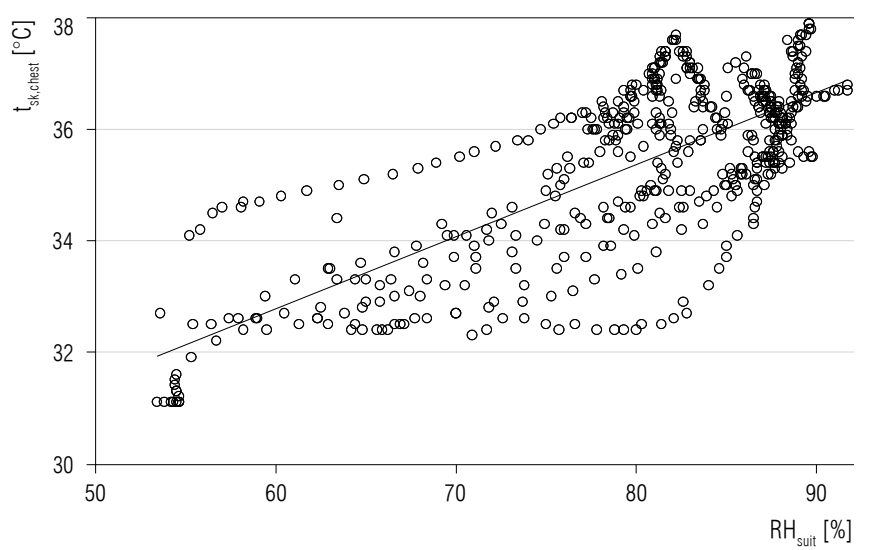

Correlation between $\mathrm{RH}_{\text {suit }}$ and $\mathrm{t}_{\text {sk, chest }}(\mathrm{R})=0.7512$

Fig. 7. Relationship between the professional fire fighters' skin temperature measured on the chest $\left(t_{\text {sk,chest }}\right)$ and relative air humidity measured between the outer and inner layer of the suit by the testing device $\left(\mathrm{RH}_{\text {suit }}\right)$

on the other hand for both experimental persons is provided in the Table 7 .

Graphical representation of the correlations of the measured quantities is presented in the Figure 2-7.

The multifactor regression analysis analyzing $t_{a c}-$ $\mathrm{t}_{\text {suit }}$ and $\mathrm{t}_{\mathrm{ac}}-\mathrm{RH}_{\text {suit }}$ relationships did not lead to improvements of observed correlations. Proportion of $\mathrm{RH}_{\text {suit }}$ in the studied relationship proved to be insignificant.

\section{DISCUSSION}

The permissible operating thermal load for the industrial population in the Czech Republic is based on the Government Regulation [20]. Nevertheless, the given limits do not apply to workers of rescue brigades in fire-fighting or liquidation of emergency situations if such persons have been recognized for this work as medically fit. In the Czech Republic the limit values for workers of rescue brigades are not legislatively determined. With regard to the safety of rescuers, however, HR should not exceed the value of 200 -age even temporarily and the body core temperature should not be higher than $38.5^{\circ} \mathrm{C}$.

Our selected load for testing the signaling device the SAM was determined in a way that the heat-humidity conditions would cover as wide range as possible and the resulting load in phases 4 and 5 would correspond to or be higher than the average load in regular interventions. This condition was met and the EPs in the last three attempts achieved or exceeded the recommended limit values of HR and the body core temperature so the exposure had to be timely interrupted due to safety reasons.
In order to measure the body core temperature in the laboratory conditions, most authors use some of invasive methods, mostly measured in anus, which is considered to be the "golden" standard [14,21]. Values measured by direct methods are considered little reliable as they can show striking differences against values acquired by invasive methods [21,22]. With respect to our used way of load (bicycle ergometer), the temperature in the ear canal was used for measuring the body core temperature. We have long experience in using this method and when strict conditions are followed, it provides very reliable results.

Direct measurement of the body core temperature by both invasive methods and in the ear canal is not possible in terrain conditions due to technical or safety reasons. Promising results are from works which calculate the body core temperature from physiological indicators easily measurable in non-rest conditions [14-16,23]. However, these methods require scanning the monitored parameters directly from the surface of the monitored person, which might be related with higher or lower level of discomfort and primarily may be the cause of faults and failures of the early warning system.

Our experiments had a very good correlation between $\mathrm{t}_{\text {suit }}$ and $\mathrm{t}_{\mathrm{ac}}(\mathrm{R}=0.9007)$. The air temperature measured under the suit $\left(\mathrm{t}_{\text {suit }}\right)$ correlated both with $\mathrm{t}_{\text {sk,ches }}$ $(\mathrm{R}=0.8928)$ and $\mathrm{HR}(\mathrm{R}=0.8613)$ very well. On the contrary, $\mathrm{RH}_{\text {suit }}$ correlated with the measured physiological indicators $t_{a c}$ and $H R$ very weakly. It may be explained that at the beginning of exercises $\mathrm{RH}_{\text {suit }}$ achieved the maximum around $90 \%$ in $10-15$ min and did not increase in the following minutes.

A good correlation between the temperature measured under the suit and the body temperature was a promising solution of this problem. Our results were achieved on a small set of persons, which does not allow deeper statistical processing and evaluation of the tightness of the found relationships. The usability of the air temperature measured under the suit as the indicator of organism load during work in protective suits will require a sufficiently large set of persons in a wide range of labour and thermal load in the laboratory and terrain conditions.

\section{CONCLUSIONS}

Based on our experiments, the air temperature measured under the suit proved to be a very good indicator of the overall load of fire fighters or rescuers. The 
technical solution of sensing the temperature under the suit using the verified SAM technology does not affect or limit fire fighters in their work and minimizes the possibility of damage to the sensor and signaling failures.

The SAM unit was subsequently also tested in field conditions. First of all, its behavior was tested in the full working temperature range and then a test at Mannequin Men (PyroMan) was performed while some fire fighter suit was attempted to achieve the certification. Another very important testing was made at the Fire Fighters Training Centre equipped with the Flashover Container Trainer. The results from the tests including detailed technical information about the SAM device can be found in Novák et al.'s article [24].

Since the found correlations between the temperature measured under the suit and indicators of work-thermal load were obtained on a small set of 2 experimental persons, the proposed limits cannot be considered as sufficiently proven and it will be necessary to verify them in a larger group of persons under the model conditions or preferably in actual interventions.

Advantages of the proposed solution compared to other similar devices (a list of comparable devices is available in [25]) are the compact design of the whole unit and its ability to evaluate thermal exposure without necessity of an uncomfortable sensor measuring temperature inside the human body (typically in the anus or in the ear).

\section{REFERENCES}

1. Ridenour M, Noe RS, Proudfoot SL, Jackson JS, Hales TR, Baldwin TN. Fire Fighter Fatality Investigation and Prevention Program. Leading recommendations for preventing fire fighter fatalities, 1998-2005. [Internet]. Ohio: Department of Health and Human Services, Centeers for Disease Control and Prevention, National Institute for Occupational Safety and Health; 2008. p. 56 [cited 2016 Dec 20]. Available from: https://www.cdc.gov/niosh/docs/2009-100/ pdfs/2009-100.pdf.

2. Trutwin W. [In difficult heat conditions]. Ratown Gorn. 1998;12(4):19-20. Polish.

3. Jirák Z, Chaloupka J, Lvončík S. [The fireman load and work and rest regimen in live action]. České Pracovní Lék. 2002;(3):118-22. Czech.

4. Kilbom Å. Physical work capacity of firemen. With special reference to demands during fire fighting. Scand J Work Environ Health. 1980;6(1):48-57, https://doi.org/10.5271/ sjweh.2634.
5. Jirák Z, Lojová E. [Results of tests of physical fitness of mine rescue workers and their working exertion in a model situation]. Pracovní Lék. 1979;31(2):43-8. Czech.

6. Hardcastle SG, Reardon FD, Kenny GP, Allen C. Assessing the work intensity of mine rescue activities and its relevance in applying heat stress management protocols. In: Panigrahi DC, editor. Mine ventilation. Proceedings of the 9th International Mine Ventilation Congress; 2009 Nov 10-13; New Delhi, India. New Delhi: Oxford \& IBH Publishing; 2009. p. 1-13.

7. Kampmann B, Bresser G, Piekarski C. Stress and strain of mine rescue teams during a standard training procedure. Appl Occup Environ Hyg. 1997;12(12):952-6, https://doi. org/10.1080/1047322X.1997.10390634.

8. Harzbecker K, Krause M, Märlein W, Schettler R. [Long term stress examinations under hypoxia in mine rescue workers]. Z Gesamte Inn Med. 1980;35(15):615-9. German.

9. Varley F. Study of heat stress exposures and interventions for mine rescue workers. Trans Soc Min Metal Explor. 2004;316:133-42.

10. ISO 7933:2004. Ergonomics of the thermal environment Analytical determination and interpretation of heat stress using calculation of the predicted heat strain. Geneva: International Organization for Standardization; 2004.

11. Jirák Z, Jokl MV, Jiráková $H$, Bajgar P. The assessment proposal for long-term and short-term tolerable hydrothermal microclimatic conditions. Physiol Res Acad Sci Bohemosl. 1997;46(4):307-17.

12. Yokota M, Berglund LG, Santee WR, Buller MJ, Karis AJ, Roberts WS, et al. Applications of real-time thermoregulatory models to occupational heat stress: Validation with military and civilian field studies. J Strength Cond Res. 2012;26(Suppl 2):37-44, https://doi.org/10.1519/JSC. 0b013e31825ceba4.

13. Moran DS, Shitzer A, Pandolf KB. A physiological strain index to evaluate heat stress. Am J Physiol. 1998;275(1): R129-34.

14. Mazgaoker S, Ketko I, Yanovich R, Held Y, Epstein Y. Measuring core body temperature with a non-invasive sensor. J Therm Biol. 2017;66:17-20, https://doi.org/10. 1016/j.jtherbio.2017.03.007.

15. Niedermann R, Wyss E, Annaheim S, Psikuta A, Davey S, Rossi RM. Prediction of human core body temperature using non-invasive measurement methods. Int J Biometeorol. 2014;58(1):7-15, https://doi.org/10.1007/s00484-0130687-2.

16. Buller MJ, Latzka WA, Yokota M, Tharion WJ, Moran DS. A real-time heat strain risk classifier using non-invasive measures of heart rate and skin temperature. Physiol 
Meas. 2008;29(12):N79, https://doi.org/10.1088/0967-33 34/29/12/N01.

17. Buller MJ. Human thermal-work strain performance optimization from wearable physiological sensors [dissertation] [Internet]. Providence: Brown University; 2015 [cited 2016 Dec 20]. Available from: https://cs.brown.edu/ research/pubs/theses/phd/2015/buller.pdf.

18. Hollmann W. [Maximum and endurance performance ability of the athlete]. 1st ed. Lepzig: J.A. Barth; 1963. p. 120. German.

19. Johnstone JA, Ford PA, Hughes G, Watson T, Garrett AT, Bioharness TM. Multivariable monitoring device. Part I: Validity. J Sports Sci Med. 2012;11(3):400-8.

20. [The Act of 28 December 2007 on determining conditions of occupational health protection. Government Regulation 2007, No. 361]. Czech.

21. Janta M, Höschele N, Senner V. The Zero Heat Flux Method and sweat loss modeling in sports: Attempts of next generation sports: Information systems. Procedia Eng. 2016;147:643-8, https://doi.org/10.1016/j.proeng. 2016.06.262.
22. Pryor RR, Seitz JR, Morley J, Suyama J, Guyette FX, Reis SE, et al. Estimating core temperature with external devices after exertional heat stress in thermal protective clothing. Prehosp Emerg Care. 2012;16(1):136-41, https:// doi.org/10.3109/10903127.2011.614047.

23. Buller JM, Tharion WJ, Cheuvront SN, Montain SJ, Kenefick RW, Castellani J, et al. Estimation of human core temperature from sequential heart rate observations. Physiol Meas. 2013;34(7):781, https://doi.org/10.1088/09 67-3334/34/7/781.

24. Novák P, Babjak J, Kot T. Thermal exposition monitoring of firefighters. MM Sci J. 2016 Nov:1482-6, https://doi. org/10.17973/MMSJ.2016_11_2016165.

25. Bryner PN, Madrzykowski MD, Stroup DW. Performance of thermal exposure sensors in personal alert safety system (PASS) devices [Internet]. Gaithersburg: U.S. Department of Commerce, National Institute of Standards and Technology; 2005 [cited 2016 Dec 20]. Available from: http://nvlpubs.nist.gov/nistpubs/Legacy/IR/nistir72 94.pdf.

This work is available in Open Access model and licensed under a Creative Commons Attribution-NonCommercial 3.0 Poland License / Ten utwór jest dostępny w modelu open access na licencji Creative Commons Uznanie autorstwa - Użycie niekomercyjne 3.0 Polska - http://creativecommons.org/ licenses/by-nc/3.0/pl/deed.en. 